\title{
Bromatological aspects of Lentinus crinitus mushroom (Basidiomycota: Polyporaceae) in agroforestry in the Cerrado
}

\author{
Carlos de Melo e SILVA-NETO ${ }^{\star *}$ (D), Diogo de Souza PINTO ${ }^{1}$, Leovigildo Aparecido Costa SANTOS², \\ Francisco J. Simões CALAÇA ${ }^{2}$
}

\begin{abstract}
Much of the diversity of mushrooms is still unknown to science. In the search for new edible mushrooms, we began to look at the traditions of Amazonian forest peoples in order to learn about the potential for edible mushrooms among other species. In particular, the Yanomami people launched the encyclopedia of food (Sanoma) in 2016 to preserve their knowledge of their own food. They demonstrated how food production can be balanced with the forest and present dozens of mushrooms that are consumed by their communities. In view of the above information, the objective of this work is to present bromatological aspects of the Lentinus crinitus mushroom from an agroforestry homegarden in the Cerrado. The specimen was collected from an agroforestry homegarden with biome forest species and agronomic species, located in the Brazilian Cerrado, in the city of Goiânia, Goiás. L. crinitus mushrooms presented $61 \%$ humidity, containing $14 \%$ crude protein, $1.5 \%$ ether extract, $26 \%$ crude fiber, and $3.4 \%$ mineral matter. Its bromatological characteristics are similar to others of commercial fungi. There is great potential for the use of the Lentinus crinitus mushroom in agroforestry yards in the Brazilian Cerrado, reconciling environmental conservation with the diversification of the production of agroextractive products.
\end{abstract}

Keywords: edible mushrooms; indigenous; tropical polypore; Yanomami.

Practical Application: With an increasing demand for food for a growing human population, the search for especially native and/or unconventional food sources has increased as well. Herein, we present the bromatological characterization of an edible fungus common in the Cerrado biome, Lentinus crinitus, whose results show its nutritional potential, despite being little known/used by the population in their diet.

\section{Introduction}

The estimated total population of fungi is estimated to be between 2.2 and 3.4 million species, with a conservatively estimated 1.5 million species considered to be very conservative (Hawksworth \& Lücking, 2017). Of this total, about $8 \%$ of this diversity is known. In Brazil, it is estimated that there is a great diversity of fungal species, especially considering that two important biodiversity hotspots, the Cerrado and Atlantic Forest, which are located occur in the tropical region of the country (Maia et al., 2015; Hawksworth \& Lücking, 2017). Much of this diversity is still totally unknown to science. Among the mushroom-producing fungi, representatives of the phylum Basidiomycota, many will be presented in the future as mushrooms with edible potential (Furlani \& Godoy, 2007). In the search for new edible mushrooms, we began to look at the traditions of Amazonian forest communities, in order to learn about the potential opportunities and advantages of edible mushrooms among other species.

In particular, the Yanomami people published the encyclopedia of food (Sanoma) in 2016 in order to preserve the knowledge of their own food, demonstrate to society how food production can be balanced with the forest, and present dozens of mushrooms as consumed by their communities (Coimbra \&
Welch, 2018). The Yanomami are indigenous South Americans who form an agro-extractive society of the tropical rainforest of the North Amazon and whose contact with the national society is relatively recent in most of its territory. The territory of this town is approximately $192,000 \mathrm{~km}^{2}$, located on both sides of the Brazil-Venezuela border in the Orinoco-Amazonas inter-fluvial region.

In Brazil, the Yanomami population was 19338 people, distributed over 228 communities in 2011, and its indigenous reserve, the Yanomami Indian Land with $96650 \mathrm{~km}^{2}$ of tropical forest, is recognized for its high relevance in terms of protection of Amazonian biodiversity (Instituto Socioambiental, 2019). Among the mushrooms presented by the Yanomami people, Lentinus crinitus (L.) Fr. (Basidiomycota: Polyporaceae) is a mushroom that is widely distributed in Brazil occurring in almost all Brazilian biomes, as well as in other South American countries. In this Amazonian community, this species is collected from the sites of "slash-and-burn agriculture", in softwoods, after the second year of mowing, growing mainly on trunks and thick branches of less dense woods, being partially burned (Coimbra \& Welch, 2018). 
Because it is a mushroom that is easier to cultivate, has abundant production, and is already traditionally used in the Yanomami feeding, L. crinitus has the potential to be studied and also consumed in a commercial production and form. As a fungus that grows on wood, the main studies related to the species address its role in the degradation of cellulose by enzymes, proteases, and laccases (Machado et al., 2016; Conceição et al., 2017; Santana et al., 2018), as well as as a competitive fungus with pathogenic fungi (e.g. Fusarium spp.) because of their accelerated growth (Figueiredo \& Silva, 2014).

Even with many biotechnological possibilities, the most basic potential of this mushroom cannot be forgotten, which is human consumption. Except for use in Yanomami traditions, among many others, this species is important in their food and studies that emphasize the potential of this species for human consumption, as well as the characteristics for its commercial production. Considering the above information, the objective of this work is to present bromatological and nutritional aspects of the Lentinus crinitus mushroom from an agroforestry homegarden in the Cerrado.

\section{Materials and methods}

The site where the specimen was collected is an agroforestry yard located in the Brazilian Cerrado in the municipality of Goiânia, Goiás. The site was implanted in the middle of 2017 with planting of agricultural species, such as coffee (Coffea arabica L.), cassava (Manihot esculenta Crantz), maize (Zea mays L.), yam (Dioscorea spp.), taioba (Xanthosoma sagittifolium Schott), ginger (Zingiber officinale R.), and banana trees (Musa spp.). Previously, the area was a forest (secondary forest) already containing arboreal species of more than ten years of development, some species being the following: jatobazeiro (Hymenaea courbaril L.), guapeva (Pouteria torta (Mart.) Radlk.), Aroeira (Myracrodruon urundeuva Fr. All.), Mango trees (Mangifera indica L.), cajazeiras (Spondia spp.), and cedar (Cedrela fissilis Vell.). In initializing the implementation area of the agroforestry homegarden, timber was harvested from the following: mango trees, guapuruvueiro (Schizolobium parahyba (Vell.) Blake), banana trees, teak (Tectona grandis L. f.), and eucalyptus (Eucalyptus spp.), for deposition in the soil, aiming at protection and decomposition to provide nutrients. The Figure 1 provides an overview of the agroforestry system.

After two years of implantation during the rainy season (mid-January), mushrooms began to appear in the different types of wood arranged in the soil. It is understood that the mushroom is only the reproductive part of the fungus and would probably present its vegetative development within dead wood. Several species of fungi and mushrooms were found growing in the locality, however Lentinus crinitus presented greater abundance among the mushrooms. From the choice of the specimens, the species was determined through the comparison of photos and with bibliographic material (Coimbra \& Welch, 2018). Morphological analysis of $L$. crinitus specimens was carried by rehydrated basidiomes according to the usual methodology for macrofungi (Largent \& Thiers, 1977; Largent et al., 1977). Sections were rehydrated in $3 \% \mathrm{KOH}$ and dyed with floxine, when necessary, and observed under a light microscope at $\times 1000$ magnification.

For analysis, about $20 \mathrm{~g}$ of mushrooms were collected (Appendix A). Subsequently, the material was sent for chemical analysis in the laboratory for determination of macronutrients and micronutrients in plant tissue. After drying, the material was submitted to leaf tissue analysis for characterization of nitrogen, phosphorus, potassium, calcium, magnesium, sulfur, manganese, sodium, organic matter, iron, copper, zinc, cobalt, and molybdenum (Calil et al., 2013) and bromatological analysis with characterization of moisture, protein, ether extract, fibers (Silva \& Queiroz, 2006; Santos et al., 2009).

After the pre-drying procedure, the sample was ground in an analytical mill with a sieve of $1 \mathrm{~mm}$ and the dry mass was determined by placing samples in a $105{ }^{\circ} \mathrm{C}$ oven for 24 hours, determining the total dry matter after calculations. The determination of the mineral matter (MM) was performed by the following method: after pre-drying $5 \mathrm{~g}$ of the ensiled material, the samples were placed in porcelain crucibles and taken to the muffler oven for burning of the organic material at a temperature ranging from $200{ }^{\circ} \mathrm{C}$ to $600{ }^{\circ} \mathrm{C}$ for a period of four hours, again to determine the total mineral matter after calculations (Silva \& Queiroz, 2006).

For the nitrogen content, the Kjedahl steam distillation apparatus was used, and the crude protein $(\mathrm{CP})$ content were calculated using the conversion factor 6.25 , according to Association of Official Analytical Chemistry (2000) and Santos et al. (2009). The analysis of total digestible nutrients (NDT), lignin, cellulose, and hemicellulose were performed according to the methodology described by Santos et al. (2009) and Silva \& Queiroz (2006).

\section{Results and discussion}

The L. crinitus mushrooms presented $61 \%$ moisture, containing $14 \%$ crude protein, $1.5 \%$ ether extract, $26 \%$ crude fiber, and $3.4 \%$ mineral matter. Its bromatological characteristics are similar to

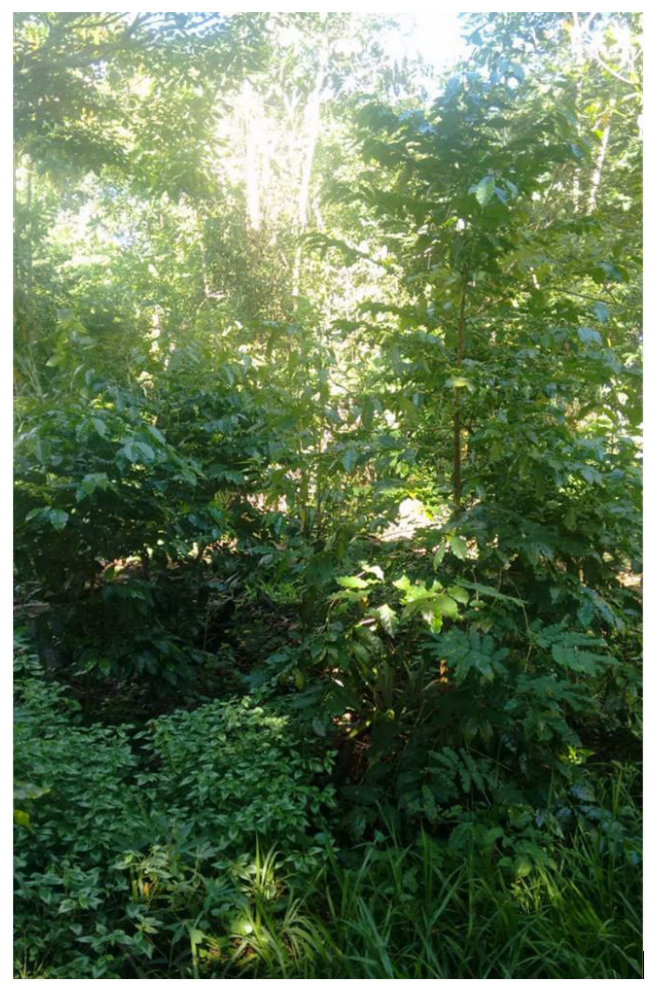

Figure 1. General view of the agroforestry homegarden in the Cerrado. 
those of commercial fungi already studied (see Table 1), presenting potential primarily in relation to the protein content and also considered similar to other fungi. The crude fiber content, on the other hand, is considered superior to the other commercial fungi. Both moisture content and crude fiber indicate that this species in this form of natural production is a more fibrous mushroom than commercial species.

In relation to the proteins contained in L. crinitus, although it is considered a high percentage in relation to protein for food, it is a mushroom with a protein-mediated relationship, being comparable to other commercial mushrooms, such as Shiitake (Lentinula edodes (Berk.) Pegler) with $18 \%$ protein (Furlani \& Godoy, 2007). The total digestible nutrients (TDN) was $25.7 \%$ and $66.9 \%$ in natura and in the dry matter, respectively, being considered high for fungus species and, thus, highlighting its potential for use as human food.

Regarding the mineral elements, the species is highlighted due to high concentrations of some elements such as nitrogen, observed at $2.24 \%$, which is related to its protein content. The other mineral elements are also relevant in the mushroom, being found in the following concentrations: $0.53 \%$ of calcium, $0.19 \%$ of phosphorus, $0.50 \%$ of potassium, 0.10 of magnesium, $0.18 \%$ of sulfur. Sodium was $109 \mathrm{ppm}$, copper $10 \mathrm{ppm}$, manganese $28 \mathrm{ppm}$, zinc $31 \mathrm{ppm}$, cobalt $011 \mathrm{ppm}$, and molybdenum $0.5 \mathrm{ppm}$.

It is noteworthy in this study that mushrooms were collected naturally, and not cultivated or produced intentionally. Due to its natural occurrence, there is preference for woods such as mangoes (Mangifera indica L.) and guapuruvuzeiros (Schizolobium parahyba. (Vell.) Blake), being considered softwoods with low density (below $0.5 \mathrm{~g} / \mathrm{cm}^{3}$ ) (see Figure 2). This result was also corroborated by the Yanomami that highlight the embaúba wood, also locally referred to as tokoli (Cecropia spp.), as preferred to find this mushroom (Coimbra \& Welch, 2018). This information on wood preference could be used as a starting point for the development of suitable substrates for the cultivation of this species. Until now, the majority of the cultivation works for this species have been developed with substrates in order to understand its enzymatic functions, however few studies have considered the potential of its fruiting (Machado et al., 2016).

We also emphasize that the substrate in which the mushroom develops directly influences its bromatological composition. Even though the species here presents an apparent preference for less dense woods, it does not mean that they cannot deveop in dense woods in the next years but with greater decomposition.
Various studies have researched commercial mushrooms, such as Pleurotus ostreatus and Lentinula edodes with different bromatological compositions, as they were cultivated on substrates such as wood base, banana leaves, and others (Andrade et al., 2008). It should also be noted that mushrooms can vary their composition according to their stage of development, presenting, for example, lower crude fiber content in earlier stages, and higher levels in later stages. In this work, the collection of the mushrooms in a stage similar to that presented by the Yanomami was prioritized, being considered almost mature mushrooms. Even so, there are reports that this species can be very fibrous if they are very late mushrooms or from previous years.

One approach that we consider important to highlight in this work is the potential utilization of Lentinus crinitus mushroom in agroforestry yards in the Brazilian Cerrado. The main objectives of the agroforestry homegarden are conservation and diversification of agroextractivist production, being the production of the mushroom and the additional advantages for the agroecosystem in this case. In this work, about $40 \mathrm{~g}$ per $50 \mathrm{~m}^{2}$ were collected at a single time, thus a hectare of agroforestry yield will be $8000 \mathrm{~g}$, or $8 \mathrm{~kg}$. If the current tray price of commercial mushrooms is around 10 reais per $100 \mathrm{~g}$, there will be a profit of 800 reais per hectare for a new commercial production site.

Morphologically, L. crinitus may present variations in basidiomas, both in the shape of the pileus popularly known as a cap, and in the stipe (stem or pedicel), which may even be absent (Pegler \& Young, 1983). Such variations, occurring at both macro and microscopic levels, explain the varieties

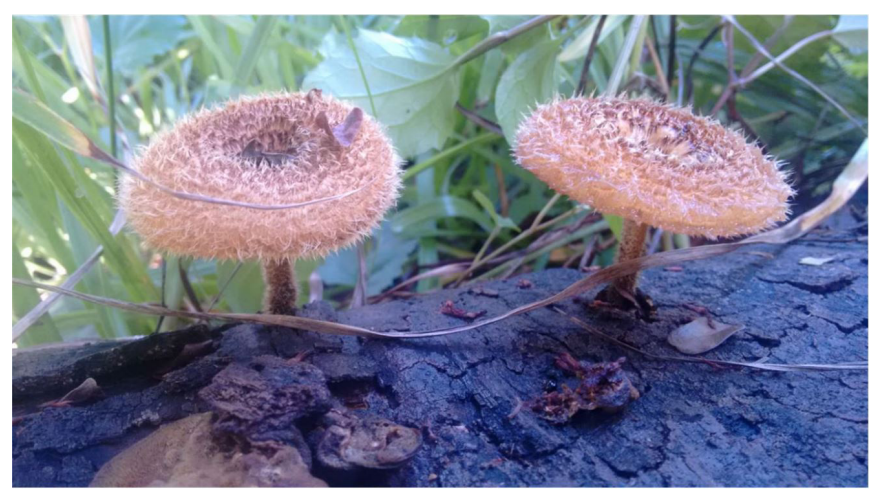

Figure 2. Lentinus crinitus mushroom growing on dead wood of guapuruvuzeiros (Schizolobium parahyba. (Vell.) Blake) in na agroforestry homegarden in the Cerrado.

Table 1. Comparison between species of mushrooms.

\begin{tabular}{|c|c|c|c|c|c|}
\hline Species & $\begin{array}{c}\text { Moisture } \\
\text { Content }\end{array}$ & $\begin{array}{l}\text { Crude } \\
\text { Protein }\end{array}$ & $\begin{array}{l}\text { Ether } \\
\text { extract }\end{array}$ & Crude Fiber & $\begin{array}{l}\text { Mineral } \\
\text { Content }\end{array}$ \\
\hline L. crinitus (L.) Fr. (present study) & $61 \%$ & $14 \%$ & $1.5 \%$ & $26 \%$ & $3.4 \%$ \\
\hline Black shimeji [Pleurotus ostreatus (Jacq.) P. Kumm.] (Carvalho et al., 2012) & - & 35.4 & $2.45 \%$ & $11.27 \%$ & $6.7 \%$ \\
\hline Shiitake [Lentinula edodes (Berk.) Pegler (Andrade et al., 2008) & - & 24.3 & $3 \%$ & $20.5 \%$ & 5 \\
\hline Champignon [Agaricus bisporus (Lange) Imbach] (Furlani \& Godoy, 2007) & - & 28.45 & - & 20.44 & 11.98 \\
\hline Shiitake (Furlani \& Godoy, 2007) & - & 18.98 & - & 41.92 & 7.04 \\
\hline White shimeji [Hypsizygus tessullatus (Bull.) Singer] (Furlani \& Godoy, 2007) & - & 22.22 & - & 39.62 & 7.65 \\
\hline Sun mushroom (Agaricus blazei Murril) (Shibata \& Demiate, 2003) & $88 \%$ & 39.80 & - & 9.65 & 7.75 \\
\hline
\end{tabular}


published for the species. Due to the different morphologies of the skeletal hyphae of the plots of the stipe and pileo, here especially of the hymenophoral weft, these can present in different textures. The stipe presents a more fibrous nature, and the pileus has a fleshy consistency, reinforcing what some works already demonstrated, and it is also noted to be primarily richer in fibers and second richest in proteins. This characteristic was found in the sun mushroom (Agaricus blazei Murrill) by Shibata \& Demiate (2003).

The table of bromatological data presents information on the main edible mushrooms in Brazil, however, there are few edible mushroom species that are native or of natural occurrence in the forests in Brazil. In the State of São Paulo, although there are no recent studies on the domestication of native mushroom species for cultivation on a commercial scale, it is known, mainly in the academic world, that in the state forests, edible species of genera are also found, such as: Agaricus, Auricularia, Lentinula, Pholiota, and Pleurotus (Ishikawa et al., 2017), still with many gaps to study.

Lentinus crinitus is just one of the twenty species of mushrooms presented by the Yanomami people, being considered by them a very abundant mushroom, not necessarily the most tasty or palatable. Many other mushrooms are preferred for food (Coimbra \& Welch, 2018). As well as knowledge about mushrooms, knowledge about the functioning of agroforestry systems is also inspired by indigenous traditional knowledge, being an important form of food production that combines agroforestry production with environmental conservation. New studies that value local and traditional knowledge of Brazil, especially the knowledge of indigenous communities, are important to recover knowledge about mushrooms, plants, and food, as well as valuing communities and positively influencing the maintenance of their territories and knowledge.

\section{Conclusions}

The mushrooms of L. crinitus present mushroom-like bromatological characteristics that are similar to those already sold in the Brazilian market. Its spontaneous appearance in agroforestry homegarden in the Brazilian Cerrado is relevant, increasing the potential of these agroecosystems by combining environmental conservation with the diversification of the production of agroextractivist products.

\section{Acknowledgements}

The authors thank for the provision and assistance in the funding the research (Project MCTIC/MAPA/MEC/SEAD-CASA-CIVIL/ CNPq no 21-2016). The author, the Technologist in Agroecology also thanks the support to the Federal Institute of Goiás to support the realization of the research.

\section{References}

Andrade, M. C. N., Minhoni, M. T. A., \& Zied, D. C. (2008). Avaliação nutricional do cogumelo shiitake [Lentinula edodes (Berk.) Pegler] em função da linhagem e do tipo de eucalipto cultivado. Food Science and Technology, 28(4), 916-921. http://dx.doi.org/10.1590/ S0101-20612008000400024.
Association of Official Analytical Chemistry - AOAC. (2000). Official methods of analysis (17th ed.). Arlington: AOAC International.

Calil, F. N., Viera, M., Schumacher, M. V., Lopes, V. G., \& Witschoreck, R. (2013). Biomassa e nutrientes em sistema agrossilvicultural no extremo sul do Brasil. Revista Ecologia e Nutrição Florestal, 1(2), 80-88. http://dx.doi.org/10.13086/2316-980x.v01n02a04.

Carvalho, C. S., Aguiar, L. V. B., Sales-Campos, C., Minhoni, M. T. A., \& Andrade, M. C. N. (2012). Determinação Bromatológica de Pleurotus ostreatus cultivado em resíduos de diferentes cultivares de bananeira. Interciencia, 37(8), 621-626. Retrieved from http:// www.redalyc.org/articulo.oa?id=33925396010

Coimbra, C. E., \& Welch, J. R. (2018). Enciclopédia dos Alimentos Yanomami (Sanöma): Cogumelos. Edited by Apiamö, R. M., Autuori, J., Ishikawa, N. K., Martins, M. S., Menolli Jr., N., Sanuma, C., Sanuma, L. R., Sanuma, M., Sanuma, O. I., \& Tokimoto, K. (2016). Instituto Socioambiental, São Paulo. 108 pp. Ethnobiology Letters, 9(2), 309-311. http://dx.doi.org/10.14237/ebl.9.2.2018.1411.

Conceição, T., Koblitz, M. G. B., Kamida, H. M., \& Góes-Neto, A. (2017). Study of the production of Lentinus crinitus (L.) Fr. lignolytic enzymes grown on agro-industrial waste. Advances in Bioscience and Biotechnology, 8(08), 259-272. http://dx.doi.org/10.4236/ abb.2017.88019.

Figueiredo, A., \& Silva, A. C. (2014). Atividade "in vitro" de extratos de Pycnoporus sanguineus e Lentinus crinitus sobre o fitopatógeno Fusarium sp. Acta Amazonica, 44(1), 1-8. http://dx.doi.org/10.1590/ S0044-59672014000100001.

Furlani, R. P. Z., \& Godoy, H. T. (2007). Valor nutricional de cogumelos comestíveis. Food Science and Technology, 27(1), 154-157. http:// dx.doi.org/10.1590/S0101-20612007000100027.

Hawksworth, D. L., \& Lücking, R. (2017). Fungal diversity revisited: 2.2 to 3.8 million species. Microbiology Spectrum, 5(4), 1-17. http:// dx.doi.org/10.1128/microbiolspec.FUNK-0052-2016. PMid:28752818.

Instituto Socioambiental - ISA. (2019). Povo: Yanomami. São Paulo. Retrieved from https://pib.socioambiental.org/pt/Povo:Yanomami

Ishikawa, N. K., Vargas-Isla, R., Gomes, D., \& Menolli, N. Jr. (2017). Principais cogumelos comestíveis cultivados e nativos do estado de São Paulo. Pesquisa \& Tecnologia, 14(2), 1-7. Retrieved from https://bit.ly/2H0AneX

Largent, D. L., \& Thiers, H. D. (1977). How to identify mushrooms to genus II: field identification of genera. Eureka: Mad River Press.

Largent, D. L., Johnson, D., \& Watling, R. (1977). How to identify mushrooms to genus III: microscopic features. Eureka: Mad River Press.

Machado, A. R. G., Teixeira, M. F. S., Kirsch, L. S., Campelo, M. D. C. L., \& Oliveira, I. M. A. (2016). Nutritional value and proteases of Lentinus citrinus produced by solid state fermentation of lignocellulosic waste from tropical region. Saudi Journal of Biological Sciences, 23(5), 621627. http://dx.doi.org/10.1016/j.sjbs.2015.07.002. PMid:27579012.

Maia, L. C., Carvalho Júnior, A. A., Cavalcanti, L. H., Gugliotta, A. M., Drechsler-Santos, E. R., Santiago, A. L. M. A., Cáceres, M. E. S., Gibertoni, T. B., Aptroot, A., Giachini, A. J., Soares, A. M. S., Silva, A. C. G., Magnago, A. C., Goto, B. T., Lira, C. R. S., Montoya, C. A. S., Pires-Zottarelli, C. L. A., Silva, D. K. A., Soares, D. J., Rezende, D. H. C., Luz, E. D. M. N., Gumboski, E. L., Wartchow, F., Karstedt, F., Freire, F. M., Coutinho, F. P., Melo, G. S. N., Sotão, H. M. P., Baseia, I. G., Pereira, J., Oliveira, J. J. S., Souza, J. F., Bezerra, J. L., Neta, L. S. A., Pfenning, L. H., Gusmão, L. F. P., Neves, M. A., Capelari, M., Jaeger, M. C. W., Pulgarín, M. P., Menolli Junior, N., Medeiros, P. S., Friedrich, R. C. S., Chikowski, R. S., Pires, R. M., Melo, R. F., Silveira, R. M. B., Urrea-Valencia, S., Cortez, V. G., \& Silva, V. F. (2015). Diversity of Brazilian fungi. Rodriguésia, 66(4), 1033-1045. http://dx.doi.org/10.1590/2175-7860201566407. 
Pegler, D. N., \& Young, T. W. K. (1983). Anatomy of the Lentinus hymenophore. Transactions of the British Mycological Society, 80(3), 469-482. http://dx.doi.org/10.1016/S0007-1536(83)80042-4.

Santana, T. T., Linde, G. A., Colauto, N. B., \& do Valle, J. S. (2018). Metallic-aromatic compounds synergistically induce Lentinus crinitus laccase production. Biocatalysis and Agricultural Biotechnology, 16, 625-630. http://dx.doi.org/10.1016/j.bcab.2018.10.018.

Santos, E. M., Zanine, A. M., Ferreira, D. J., Oliveira, J. S., Pereira, O. G., Cecon, P. R., \& Vasconcelos, W. A. (2009). Chemical composition and dry matter in situ degradability of arboreal legumes from Brazilian semi-arid region. Archives of Veterinary Science, 14(2), 96-102. http://dx.doi.org/10.5380/avs.v14i2.13618.

Shibata, C. K. R., \& Demiate, I. M. (2003). Cultivo e análise da composição química do cogumelo do sol. Ciências Biológicas e da Saúde, 9(2), 21-32. Retrieved from http://www.revistas2.uepg.br/index.php/ biologica/article/view/361/369

Silva, D. J., \& Queiroz, A. C. (2006). Análise de alimentos: métodos químicos e biológicos (3. ed.) Viçosa: UFV. 
Appendix A. Mushrooms Lentinus crinitus collected.

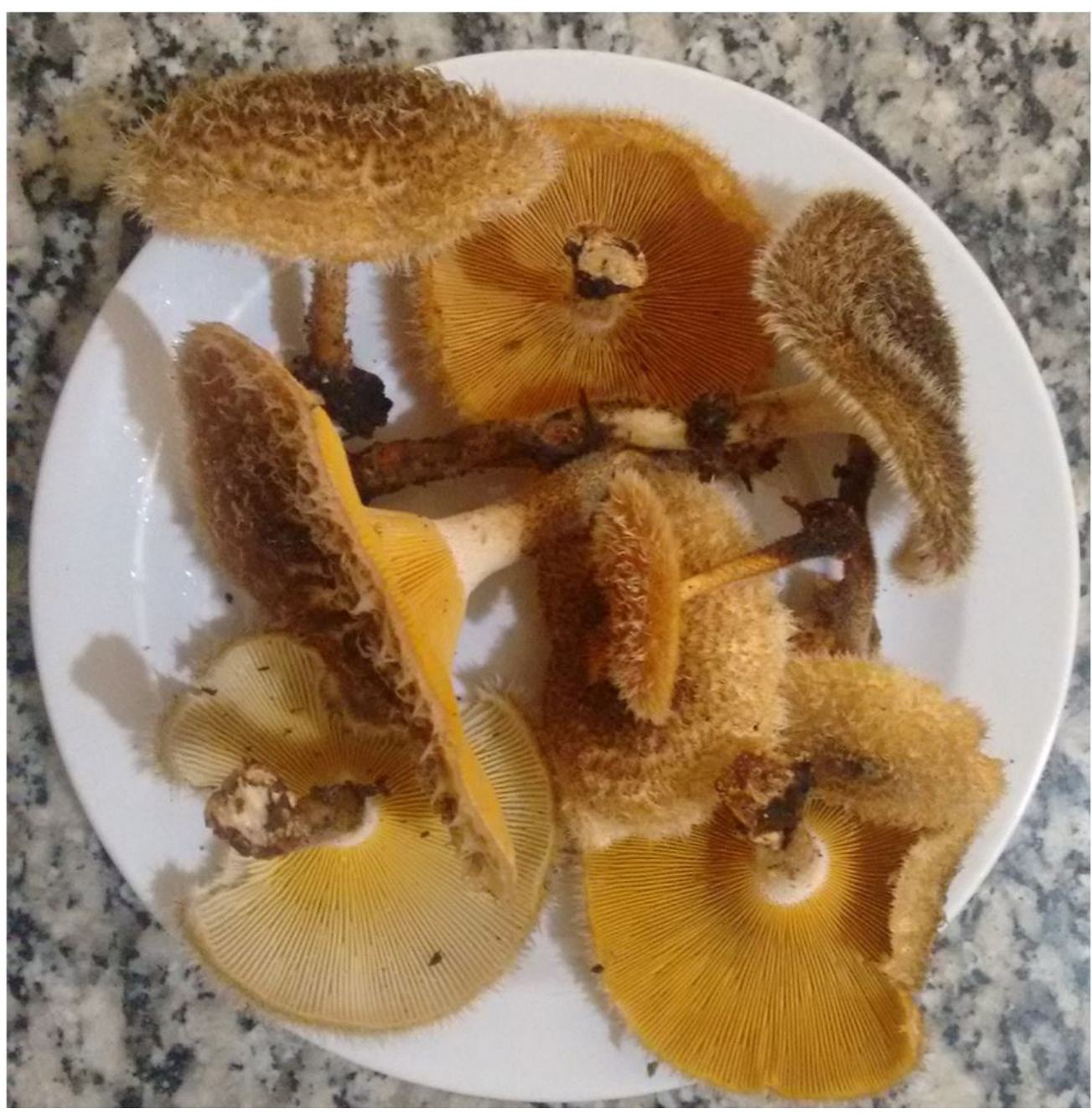

